\title{
ОСОБЛИВОСТІ ДЕЯКИХ СТРУКТУРНО-ФУНКЦІОНАЛЬНИХ ПОКАЗНИКІВ ШЛУНОЧКІВ У ХВОРИХ НА ХРОНІЧНЕ ОБСТРУКТИВНЕ ЗАХВОРЮВАННЯ ЛЕГЕНЬ В УМОВАХ КОМОРБДНОСТІ $З$ ГІПЕРТОНІЧНОЮ ХВОРОБОЮ
}

\author{
๑Ю. Г. Бурмак, С. І. Треумова, Є. Є. Петров, Т. А. Іваницька, І. В. Іваницький \\ ВДНзу «Українська медична стоматологічна академія», м. Полтава
}

РЕЗЮМЕ. Коморбідність хронічного обструктивного захворювання легень (ХОЗЛ) із гіпертонічною хворобою (ГХ) була й залишається важливою проблемою. Вважають, що порушення структурно-функціонального стану правого шлуночка (ПШ) підвищує ризик розвитку фатальних ускладнень у таких хворих, а дисфункція лівого шлуночка (ЛШ) $є$ незалежним прогнозонегативним фактором.

Мета дослідження - вивчити особливості структурно-функціональних показників шлуночків у хворих на ХОЗЛ в умовах коморбідності з ГХ.

Матеріали та методи. Було проведено ехокардіографічне дослідження (Toshiba SSA, 380A Powerwision (Японія) 32 хворих на ХОЗЛ (ІІ стадія) із коморбідною ГХ (ІІ ступінь). Отримані дані зіставляли з аналогічними у 32 хворих на ХОЗЛ (ІІ стадія) та практично здорових осіб ( $n=15)$.

Результати. У хворих на ХОЗЛ в поєднанні з ГХ спостерігалось зниження швидкості раннього, пізнього діастолічного наповнення шлуночків та їх співвідношення $(\mathrm{P}<0,001)$; час ізоволюмічної релаксації ПШ та лШ перевищував такий у хворих на ХОЗЛ, відповідно, на 75 \% та 44 \%. У коморбідних хворих виявлено зниження фракції скорочення ПШ (на 12 \%), швидкості кровотоку у вихідному тракті - на 33 \%, порівняно із практично здоровими особами $(P<0,001)$. На відміну від Хворих на ХОЗЛ, у коморбідних пацієнтів відбувалося зниження максимальної швидкості кровотоку у вихідному тракті ЛШ на 20 \% (на третину, порівняно із практично здоровими (P<0,001)), а також спостерігали зниження фракції викиду ЛШ на 7,8 \% і на 13 \% -ударного індексу $($ Р<0,001), за наявності тенденції до зниження серцевого індексу.

Висновки. У хворих на ХОЗЛ з коморбідною ГХ наявні ознаки вираженої діастолічної дисфункції шлуночків із раннім розвитком систолічної дисфункції, що є прогнозонегативним фактором та має ураховуватись при виборі стратегії і тактики лікування таких пацієнтів.

КЛючОВІ СлОВА: хронічна обструктивна хвороба легень; коморбідність; дисфункція міокарда.

Вступ. Коморбідність хронічного обструктивного захворювання легень (ХОЗЛ) із гіпертонічною хворобою (ГХ) була й залишається найбільш важливою проблемою [1, 2] - її поширеність перевищує 70 \% та вона складає більше 50 \% в структурі смертності. Вважають, що порушення структурно-функціонального стану правого шлуночка (ПШ) підвищує ризик розвитку фатальних ускладнень у таких хворих, а дисфункція лівого шлуночка (ЛШ) $\epsilon$ незалежним прогнозонегативним фактором.

Мета дослідження - вивчити особливості структурно-функціональних показників шлуночків у хворих на ХОЗЛ в умовах коморбідності з ГХ.

Матеріал і методи дослідження. Ехокардіографічне дослідження (Toshiba SSA, 380A Powerwision (Японія) було проведено у 32 хворих (чоловіків - 21, жінок-11) на ХОЗЛ (ІІ стадія) із коморбідною ГХ (II ступінь), які склали основну групу; середній вік обстежених дорівнював $(54,8 \pm 2,6)$ років. Показники зіставляли з аналогічними у 32 хворих на ХОЗЛ (група порівняння), що не відрізнялись від основної за статтю, віком, тривалістю захворювання, та практично здоровими особами ( $n=15)$; розбіжності між показниками, що порівнювались, вважали достовірними при $\mathrm{P}<0,05$.

Результати й обговорення. У хворих на ХОЗЛ в поєднанні зГХ спостерігалось зниження швидкості раннього, пізнього діастолічного наповнення шлуночків та їх співвідношення $(P<0,001)$, при цьому час ізоволюмічної релаксації ПШ перевищував такий групи порівняння на $75 \%$, а ЛШ - на $44 \%$ $(P<0,001)$. Це свідчило про наявність у хворих на ХОЗЛ із коморбідною ГХ діастолічної дисфункції шлуночків. З'ясовано, що фракція скорочення ПШ у хворих основної групи $((19,8 \pm 0,7) \%)$ була зниженою на $12 \%$, швидкість кровотоку у вихідному тракті становила $(0,6 \pm 0,003)$ м/с і була на 33 \% нижчою, порівняно із практично здоровими особами $(\mathrm{P}<0,001)$. Виявлено, що у хворих основної групи максимальна швидкість кровотоку у вихідному тракті ЛШ була зниженою на 20 \% порівняно із групою зіставлення, а порівняно із практично здоровими особами - на третину $(P<0,001)$. На відміну від хворих на ХОЗЛ, у пацієнтів із коморбідною патологією спостерігалось зниження фракції викиду ЛШ на 7,8 \%, ударного індексу - на $13 \%(P<0,001)$ за наявності тенденції до зниження серцевого індексу $\left((2,4 \pm 0,3) \pi /\right.$ хв/ $\mathrm{M}^{2}$ проти $(3,0 \pm 0,3) \pi /$ в $/ \mathrm{M}^{2}$, що відображало наявність систолічної дисфункції ЛШ, що не суперечить попередньо отриманим даним $[3,4]$.

Висновки. У хворих на ХОЗЛ та коморбідну ГХ наявні ознаки вираженої діастолічної дисфункції шлуночків із раннім розвитком систолічної дисфункції, що $\epsilon$ прогнозонегативним фактором та має враховуватися при виборі стратегії і тактики лікування таких пацієнтів. 
Огляди літератури, оригінальні дослідження, погляд на проблему, ювілеї ЛІТЕРАТУРА

1. Оцінка динаміки клініко-лабораторних показників у лікуванні хворих на хронічне обструктивне захворювання легень у поєднанні з остеоартритом / В. М. Ждан, Г. С. Хайменова, І. В. Іваницький [та ін.] // Актуальні проблеми сучасної медицини: Вісник української медичної стоматологічної академії. - 2017. - № 2 (58). - С. 129-131.

2. Клінічний перебіг та лікування поєднаної патології: ХОЗЛ і АГ / М. М. Потяженко, К. Є. Іщейкін, Н. О. Люлька [та ін.] // Актуальні проблеми сучасної медицини. Вісник української медичної стоматологічної академії. 2012. - № 1-2 (37-38). - С. 139-144.

\title{
REFERENCES
}

1. Zhdan, V.M., Khaymenova, H.S., Ivanytskyi, I.V., Volchenko, H.V., \& Tkachenko, M.V. (2017). Otsinka dynamiky kliniko-laboratornykh pokaznykiv u likuvanni khvorykh na khronichne obstruktyvne zakhvoriuvannia lehen u poiednanni $z$ osteoartrytom [Evaluation of the dynamics of clinical and laboratory parameters in the treatment of patients with chronic obstructive pulmonary disease in combination with osteoarthritis]. Aktualni problemy suchasnoi medytsyny: Visnyk ukrainskoi medychnoi stomatolohichnoi akademii - Actual Issues of Modern Medicine: Journal of Ukrainian Medical Stomatological Academy, 2 (58), 129-131 [in Ukrainian].

2. Potiazhenko, M.M., Ishcheikin, N.O. Liulka, Ishcheikin, K.Ye., \& Liulka, N.O. (2012). Klinichnyi perebih ta likuvannia poiednanoi patolohii: KhOZL i AH [Clinical course and treatment of combined pathology: COPD and AG]. Aktualni problemy suchasnoi medytsyny: Visnyk ukrainskoi medychnoi stomatolohichnoi akademii - Actual Issues of Modern Medicine: Journal of Ukrainian Medical Stomatological Academy, 1-2 (37-38), 139-144.

3. Оцінка показників функції зовнішнього дихання у хворих на хронічне обструктивне захворювання легень в поєднанні з ішемічною хворобою серця на тлі метаболічного синдрому / С. І. Треумова, $€$. $€$. Петров, Ю. Г. Бурмак, В.П.Боряк // Вісник проблем біології і медицини. - 2016. - № 1. - С. 118-123.

4. Вплив ішемічної хвороби серця та метаболічного синдрому на показники функції зовнішнього дихання у хворих на хронічне обструктивне захворювання легень / С. І. Треумова, Є. Є. Петров, Ю. Г. Бурмак, Т. А. Іваницька // Здобутки клінічної і експериментальної медицини. - 2016. - № 2. - С. 141.

3. Treumova, S.I., Petrov, Ye.Ye., Burmak, Yu.H., Boriak, V.P. (2016). Otsinka pokaznykiv funktsii zovnishnoho dykhannia u khvorykh na khronichne obstruktyvne zakhvoriuvannia lehen $v$ poiednanni $z$ ishemichnoiu khvoroboiu sertsia na tli metabolichnoho syndromu [Evaluation of indicators of external respiration function in patients with chronic obstructive pulmonary disease combined with coronary heart disease on the background of metabolic syndrome]. Visnyk problem biolohii i medytsyny - Journal of Problems of Biology and Medicine, 1, 118-123.

4. Treumova, S.I., Petrov, Ye.Ye., Burmak, Yu.H., \& Ivanytska, T.A. (2016). Vplyv ishemichnoi khvoroby sertsia ta metabolichnoho syndromu na pokaznyky funktsii zovnishnoho dykhannia u khvorykh na khronichne obstruktyvne zakhvoriuvannia lehen [Influence of coronary heart disease and metabolic syndrome on parameters of external respiration in patients with chronic obstructive pulmonary disease]. Zdobutky klinichnoi i eksperymentalnoi medytsyny-Achievements of Clinical and Experimental Medicine, 2, 141 [in Ukrainian].

\section{ОСОБЕННОСТИ НЕКОТОРЫХ СТРУКТУРНО-ФУНКЦИОНАЛЬНЫХ ПОКАЗАТЕЛЕЙ ЖЕЛУДОЧКОВ У БОЛЬНЫХ ХРОНИЧЕСКОЙ ОБСТРУКТИВНОЙ БОЛЕЗНЬЮ ЛЕГКИХ В УСЛОВИЯХ КОМОРБИДНОСТИ С ГИПЕРТОНИЧЕСКОЙ БОЛЕЗНЬЮ}

\author{
○Ю. Г. Бурмак, С. И. Треумова, Е. Е. Петров, Т. А. Иваницкая, И. В. Иваницкий \\ ВГУзУ «Украинская медицинская стоматологическая академия», г. Полтава
}

РЕЗЮМЕ. Коморбидность Хронической обструктивной болезни легких (ХОБЛ) и гипертонической болезни (ГБ) была и остается важлной проблемой. Считается, что нарушение структурно-функционального состояния правого желудочка (ПЖ) повышает риск развития фатальных осложнений у таких больных, а дисфункция левого желудочка (ЛЖ) является независимым прогнозонегативным фактором.

Цель исследования - изучить особенности структурно-функциональных показателей желудочков у больных ХОБЛ в условиях коморбидности с ГБ.

Материалы и методы. Было проведено ехокардиографическое обследование (Toshiba SSA, 380A Powerwision (Япония) 32 больных ХОБЛ (II стадия) с коморбидной ГБ (II степень). Полученные результаты сопоставляли с аналогичными 32 больных ХОБЛ (II стадия) и практически здоровыми лицами ( $\mathrm{n=15}$ ).

Результаты. У больных ХОБЛ в сочетании с ГБ наблюдалось снижение скорости раннего, позднего диастолического наполнения желудочков и их соотношения $(\mathrm{P}<0,001)$, время изоволюмической релаксации ПЖ и лЖ превышало таковое больных ХОБЛ, соответственно, на 75 \% и 44 \%. У коморбидных больных обнаружено сниже- 
Огляди літератури, оригінальні досліджння, погляд на проблему, ювілеї

ние фракции укорочения Пж (на 12 \%), на 33 \% - скорости кровотока в выходном тракте, по сравнению с практически здоровими лицами ( $<0,001)$. В отличие от больных ХОБЛ, у коморбидных пациентов имело место снижение максимальной скорости кровотока в выходном тракте лЖ - на 20 \% (на треть по сравнению с практически здоровыми (Р<0,001)), а также наблюдалось снижение фракции выброса лЖ на 7,8 \% и на 13 \% -ударного индекса $(P<0,001)$ при тенденции к снижению сердечного индекса.

Выводы. У больных ХОБЛ и коморбидной ГБ наблюдаются признаки выраженной диастолической дисфункции желудочков и раннее развитие систолической дисфункции, что является прогнозонегативным фактором и должно учитываться при выборе стратегии и тактики лечения таких пациентов.

КЛючЕВЫЕ СЛОВА: хроническая обструктивная болезнь легких; коморбидность; дисфункция міокарда.

\title{
PECULIARITIES OF SOME STRUCTURAL-FUNCTIONAL INDICATORS OF VENTRICLES IN PATIENTS WITH CHRONIC OBSTRUCTIVE LUNG DISEASE IN CONDITIONS OF COMORBIDITY WITH ARTERIAL HYPERTENSION
}

\author{
๑Yu. G. Burmak, S. I. Treumova, E. E. Petrov, T. A. Ivanytskaya, I. V. Ivanytsky \\ Ukrainian Medical Dental Academy, Poltava
}

SUMMARY. The comorbidity of chronic obstructive pulmonary disease (COPD) and arterial hypertension (AH) has been and remains an important problem. It is believed that a violation of the structural and functional state of the right ventricle (RV) increases the risk of fatal complications in such patients. Left ventricular dysfunction (LV) is an independent prognostic negative factor.

The aim of the study was to examine the features of the structural and functional indices of the ventricles in patients with COPD in comorbidity with hypertension.

Material and Methods. An echocardiographic study was conducted (Toshiba SSA, 380A Powerwision, Japan) in 32 patients with COPD (stage II) with comorbid hypertension (grade 2). The results were compared with similar 32 patients with COPD (stage II) and practically healthy persons $(n=15)$.

Results. In patients with COPD in combination with $\mathrm{AH}$, there was a decrease in the rate of early, late diastolic filling of the ventricles and their ratio $(P<0.001)$. The time of isovolumic relaxation of the RV and the LV exceeded in patients with COPD, respectively, by $75 \%$ and $44 \%$. In comorbid patients, a reduction in the fraction of truncation of the RV (by $12 \%$ ) was detected, by $33 \%$ - the velocity of blood flow in the output tract compared to practically healthy individuals $(P<0.001)$. In contrast to patients with COPD, in comorbid patients there was a decrease in the maximum flow velocity in the output tract of the left ventricle by $20 \%(P<0.001)$, a decrease in the LV ejection fraction by $7.8 \%$ and $13 \%-$ stroke volume $(P<0.001)$ with a tendency to decrease the cardiac index.

Conclusions. In patients with COPD and comorbid AH, there are signs of severe diastolic ventricular dysfunction and early development of systolic dysfunction, which is a predictive-negative factor and should be taken into account in the strategy and tactics of treatment of such patients.

KEY WORDS: chronic obstructive pulmonary disease; comorbidity; myocardial dysfunction.

Отримано 13.02.2018 